\title{
The Social and Ethical Acceptability of NBICs for Purposes of Human Enhancement: Why Does the Debate Remain Mired in Impasse?
}

\author{
Jean-Pierre Béland • Johane Patenaude • \\ Georges A. Legault • Patrick Boissy • \\ Monelle Parent
}

Received: 4 August 2011 /Accepted: 16 October 2011 /Published online: 11 November 2011

(C) The Author(s) 2011. This article is published with open access at Springerlink.com

\begin{abstract}
The emergence and development of convergent technologies for the purpose of improving human performance, including nanotechnology, biotechnology, information sciences, and cognitive science (NBICs), open up new horizons in the debates and moral arguments that must be engaged by philosophers who hope to take seriously the question of the ethical and social acceptability of these technologies. This article advances an analysis of the factors that contribute to confusion and discord on the topic, in order to help in understanding why arguments that form a part of the debate between transhumanism and humanism result in a philosophical and ethical impasse: 1 . The lack of clarity that emerges from the fact that any given argument deployed (arguments based on nature and human nature, dignity, the good life) can serve as the basis for both the positive and the negative evaluation of NBICs. 2. The impossibility of providing these arguments with foundations that will enable others to deem them acceptable. 3 . The difficulty of applying these same arguments to a specific situation. 4. The
\end{abstract}

J.-P. Béland $(\bowtie)$

Département des sciences humaines, Université du Québec

à Chicoutimi,

Chicoutimi, Québec, Canada G7H 2B1

e-mail: jpbeland@uqac.ca

J. Patenaude $\cdot$ G. A. Legault $\cdot$ P. Boissy $\cdot$ M. Parent

Université de Sherbrooke,

Sherbrooke, Québec, Canada ineffectiveness of moral argument in a democratic society. The present effort at communication about the difficulties of the argumentation process is intended as a necessary first step towards developing an interdisciplinary response to those difficulties.

Keywords Debate about transhumanism and humanism · Human enhancement · Philosophicalethical impasse $\cdot$ Social-ethical acceptance

The emergence and development of convergent technologies for the purpose of improving human performance [33], including nanotechnology, biotechnology, information technology, and cognitive science (NBICs), open up new horizons in the debates and moral arguments that must be engaged by philosophers who hope to take seriously the question of the ethical and social acceptability of these technologies. Debates over the convergence of NBICs for the purpose of human enhancement often entail the following polarization:

- On one side are those who are 'unconditionally for', the people known as transhumanists, such as Naam [27], Bostrom [5] and Kurzweil [22]. These authors invoke moral arguments related to freedom and autonomy, nature and human nature, to legitimize the position that the only way for human beings to escape human incompleteness is to implement the convergence of technologies on the nano 
scale, thus making it possible to surmount biological limitations (the fragility of being; disease and death) until the coming of the human-machine hybrid or immortal cyborg - the posthuman [19].

- On the other side are those who are 'unconditionally against', commonly known as the humanists, like Fukuyama $[15,16]$ and Habermas [18]. These authors reply by wielding the semantic incompatibility of moral arguments based on the nature, dignity, and good life of fragile mortal human beings as evidence of limitations that it is appropriate to impose in order to restrain, indeed altogether prohibit, the development of these new nanotechnological powers in order to alter human beings and thus dominate first human nature and then nature as a whole.

As has been pointed out by Jean-Pierre Dupuy [14], philosophical debates on the ethical foundations of nanotechnologies have become so routine that one could number the arguments constantly deployed and observe that when one person invokes Argument Number Ten, someone else invariably replies with a corresponding counterargument: 'The same arguments are always served up, and they are always answered with the same counter-arguments'. Why is the philosophical debate reduced to this clash of incompatible arguments and counterarguments? In other words, why has the debate so far been destined to remain mired in impasse? This is the preliminary question to which we want to formulate some replies.

If we wish to grasp the relevance of philosophy to the sphere of the social and ethical acceptability of the development of new technologies, we must become familiar with and understand those sources of the conflict that account for the way the discussion ends in impasse.

In the present article, we will advance the analysis presented by Patenaude et al. [30], which identified the threefold nature of a moral argument, the seven core meanings of the moral arguments usually deployed in debate about nanoethics, and the five moral stances that underlie those seven moral arguments. In the polarized climate of discussion between transhumanists and humanists, the main arguments that clash are those based on: nature and human nature; dignity; the good life; autonomy; and rights. Focusing exclusively on these arguments, our analysis will show how four factors help us understand why the debate between transhumanism and humanism has been incapable of a productive outcome.

1. The ambiguity that results from the fact that a single deployed argument (nature and human nature; dignity; the good life) can serve as the basis for both a positive and negative evaluation of the development of NBICs, because the core meaning of the argument's moral utterance is not specified.

2. The impossibility of providing these arguments with foundations that will enable others to deem them acceptable.

3. The difficulty of applying these arguments to a specific situation.

4. The ineffectiveness of moral argument in a democratic society.

To undertake this philosophical process of clarification, it was necessary to examine all the texts published in the journal NanoEthics since it was founded in 2007. From among these texts, we retained 14, based on two criteria: articles that discuss moral arguments in favor of or against nanotechnologies; and articles on meta-ethics. We also analyzed reports (including the National Science Foundation Report, [1]) and recent books that met the same criteria.

\section{The Arguments' Ambiguity}

The ambiguity of the arguments used (arguments based on nature and human nature, dignity, and the good life) in these discussions between humanism and transhumanism represents one factor contributing to confusion and philosophical impasse. How are we to account for this? We can do so using an analytic model that relies on a definition of the notion of ambiguity in philosophy. "We are dealing with an ambiguity when the word or phrase has more than one meaning within a given context and we are uncertain which one to choose' ([29]: 107). A model of this definition appears in Fig. 1 below:

Based on this analytic model, we will see in what follows that the arguments based on nature and human nature, dignity, and the good life, as found in the context of the moral utterances of the moral 
Argument in the context of debate

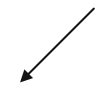

A. Affirmative, humanist sense vs

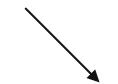

B. Critical, transhumanist sense
Fig. 1 Model for the analysis of ambiguity in an argument in the context of debate. A. Affirmative, humanist sense vs B. Critical, transhumanist sense

arguments advanced in the debate, constitute factors contributing to ambiguity and discord and lead to philosophical and ethical impasses.

The Ambiguity of the Argument Based on Nature and Human Nature

In the argument based on nature and human nature that makes it possible to evaluate using convergent NBICs for human enhancement, the core meaning of the moral utterance is a prescription. This moral utterance specifies what we must do or not do, taking into account the knowledge we have of the laws that govern nature and our own human nature. But the argument is ambiguous, because it refers to at least two contradictory justifications for the moral utterance in the context of the debate between humanism and transhumanism:

Sense A: Humanist "Nature" in its religious sense implies everything God has created, laws that have been handed down, and the order or plan that serves as the criterion for judgment. For humanists like Fukuyama, the human being who has been enhanced with NBICs, the cyborg that the transhumanist Stock [35] identifies with the 'fusion of technology and biology', contradicts this divine and immutable order of nature. However, it also threatens the Western secular belief in a human nature as provisionally fixed at the present day, in the sense that it is not 'infinitely plastic' in its biological complexity and can only vary within a certain range determined by life: 'Fukuyama maintains that human nature must be considered fixed even if it isn't, because the consequences of extreme human plasticity would be the disappearance of democratic values' such as equality and autonomy ([3]: 263). Democracies can and must restrict these consequences for human nature: 'True freedom means the freedom of political communities to protect the values' associated with human nature ([15]: 218).

Sense B: Critical Transhumanists like Kurzweil [22] reply that the essence of the human being resides not in our limitations, but in our capacity to overcome them:

Then perhaps our basic disagreement is over the nature of being human. To me, the essence of being human is not our limitations - although we do have many-it's our ability to reach beyond our limitations. We didn't stay on the ground. We didn't even stay on the planet. And we are already not settling for the limitations of our biology.

Kurzweil [22] thus prefers openness to human enhancement by NBICs over a static utopia of human nature. The biological nature of the human being can vary without limitations at the whim of the development of these convergent technologies (NBICs) of which it is itself the matrix: '[T]here are no essential barriers to our emulating these ways in our technologies, and we are already well down this path.' Human enhancement by means of the development of these technologies, carried out in order to transcend the biological nature of the human being, would thus have nothing sinister about it. It would be a part of the tradition of human effort to continue that process of self-appropriation that is constitutive of humanity. It is for this reason that prohibiting the development of NBICs is illegitimate. Thus for the philosopher Dominique Lecourt [26], as expressed in his book Humain post humain, ethics cannot remain limited by the formulation of prohibitions in the name of human nature, because the singularity process (the process of hybridizing the human with the technological) is constitutive of human nature:

And if we place the human being within the 'flux of the living', as is appropriate, technological reality cannot be thought about without viewing it as an essential dimension of human beings, whose very nature it is to manifest themselves in perpetual becoming, propelled by an ongoing constructive and destructive dynamic.

\section{The Impasse}

From the ambiguous potential for both sense $\mathbf{A}$ and sense $\mathbf{B}$ to be implied in the argument based on nature 
and human nature flows the fact that this argument can be used to evaluate the development of NBICs both positively and negatively. The fullest philosophical critique of the equivocal interplay between senses $\mathbf{A}$ and $\mathbf{B}$ in interpreting the concept of nature, especially from a moral perspective, is that advanced by John Stuart Mill ([23]: 672) in his critical essay entitled 'Nature' (published in the posthumous work Three Essays on Religion, 1874):

The word 'nature', says Mill, has two main senses: it denotes either the total system of things [both artificial and natural] and all their properties, or things the way they would be, absent all human intervention. The doctrine that recommends that human beings follow nature is absurd, because a human being cannot do otherwise. Under the second sense, the doctrine that recommends that human beings follow nature, that is, the spontaneous [natural] course of things, as a model for their own actions is irrational and immoral: irrational because every human action consists of changing the course of nature thus defined and every useful action consists of improving it; immoral because the course of things is full of events that are unanimously deemed to be odious when they result from the human will.

The ambiguity of the terms 'nature' and 'human nature' creates a dialogical impasse in the debate between humanism and transhumanism because it reflects the existence of at least two contradictory justifications for maintaining that the moral utterance follows the laws of nature. So long as there is no philosophical discussion of the grounds for adopting one conception of nature over the other, the impasse will persist.

\section{The Ambiguity of the Argument Based on Dignity}

In moral utterances of the Kantian kind, we find the moral prescription that expresses the condition for possibility of our moral action: 'Act in such a manner that you treat humanity, both in your own person, and in the person of any other, always at the same time as an end and never simply as a means' ([21]: 36). Robert Theis [37] argues that this formulation of the categorical imperative, which affirms the status of humanness as an end in itself, forms the center of gravity of Kant's various statements of principle and duty. On this view, the core meaning of the moral argument based on dignity is that it is the nature of humanity, in one's own person and the person of others, to be an end. In the debate between humanism and transhumanism, this type of argument is ambiguous, because it can imply at least two contradictory and incompatible senses:

Sense A: Humanist Fukuyama [15] invokes the return of human dignity as a constraint on autonomy in the Kantian sense: 'It is the existence of free will that leads to Kant's well-known conclusion that human beings are always to be treated as ends and not as means.' For some humanists, the cyborg (the humanmachine hybrid) manifests as a transgression of the principle of human beings themselves constituting ends. Thus dignity consists of making technological choices founded on morally acceptable goals, in order not to treat human beings as objects or means but to treat them, rather, as ends in themselves, in this way limiting the consequences of those technological developments that affect our physical, psychological or cultural identity.

Sense B: Critical For transhumanists, however, the natural end of the human being flows from the free choice to evolve towards conceptions of the cyborg in order to allow for the fulfillment of the human desire to be liberated from finiteness (biological limitations, diseases, death): 'The convergence of humanity and technology seems to be the natural end of moving this reasoning into the realm of speculation. The concepts of "cyborgs" as technically enhanced humans or as humanly enhanced technology can be raised' ([17]: 80 ). This natural end is associated with the concept of dignity-autonomy without constraints, which constitutes the condition of a person who is selfdetermining by virtue of her or his own nature. On this view, humans obey only the law they invent. This law promotes the freedom of human beings in 'their capacity for endless reinvention of their way of being human according to the fulfillments of their specific genius' ([26]: 48).

\section{The Impasse}

The ambiguity created by the twofold interpretation of the concept of dignity (senses $\mathbf{A}$ and $\mathbf{B}$ ) lies at the 
heart of debates between transhumanism and humanism and flows thence to be encountered more or less everywhere. Thus it can be used as a way of evaluating the NBIC process positively or negatively. It represents a real problem for the philosopher Brownsword [6], who wonders whether the normative invention of nanomedicine is the least of our worries:

The problem is showcased by modern debates concerning the ethics and regulation of biotechnology. Here, the idea of human dignity has appeared in two very different roles, in the one case acting in support of individual autonomy (human dignity as empowerment) and, in the other case, acting as a constraint on autonomy (human dignity as constraint).

The impasse can be partly resolved by clarifying the core meaning of the moral utterance that makes the appeal to dignity. In the present case, three different core meanings are referred to: the Kantian one, the one based on autonomy, and the one based on rights. Once the core meaning has been clarified, we can deal with that aspect of the impasse that relates to the justification for adopting one moral argument or the other.

The Ambiguity of the Argument Based on the Good Life

In this same context of debates between humanism and transhumanism, arguments made on the basis of the good life seek to evaluate human choices according to their consequences for the conditions of human life. Thus one finds in Paul Ricoeur's celebrated definition of the ethical purpose of the good life the component of individual choice focused on happiness while taking others and institutions into account: 'aiming at the "good life" with and for others, in just institutions' ([31]: 172). On this view, a moral evaluation of the good life rests on this question: What are the consequences of human enhancement by means of NBICs for the very conditions of life, both individual and social? For example, what risks to our current human conditions of life are entailed by thinking and acting with the idea of creating an immortal cyborg? Is this notion of transforming ourselves in order to achieve infinity, with no biological, cultural, or affective limitations ('infinite knowledge, infinite intelligence, infinite beauty, infinite creativity, and infinite love') ([22]: 476) in continuity with our current experience of a happy human life in the awareness of finiteness and death, or does it represent a break with it? In the debate between humanists and transhumanists, the argument based on the good life is ambiguous because it invokes at least two contradictory senses:

Sense A: Humanist What conception of the good life do humans have? Humanists like Ricoeur generally adopt a conception of happiness as an ultimate state to which humanity aspires. Most humanists are in the habit of opposing the acceptance of finiteness to the immoderate desire for infiniteness, a boundless desire that the Greeks denounced as hubris and that causes humanity to descend into self-destruction and the failure represented by despair. For the true happiness of the human being as found in historical and concrete existence consists not in acting out the immoderate desire to conquer human finiteness (limitations, aging, fear of death) in order to achieve infiniteness (the joy of being infinite and immortal), but in the act of accepting suffering and finiteness: 'Man is the Joy of Yes in the sadness of the finite' ([32]: 140). Humanists in general oppose this argument to technological rationality, which strikes them as consisting of that ideological degeneration that leads to existentialist failure (humanity's self-destruction). For example, '[H]umanist wisdom requires coming to terms with the natural finiteness that affects every human being' ([4]: 64), because the paradoxical selfsuppression of both the self and the world flows from our scientific world, which attends to human beings' imaginary needs and limitless desires to transcend finiteness in order to carry out our transformation into an immortal cyborg. 'Posthuman utopias derive from a similar ambition. What is strange is that some people don't hesitate to defend the paradox that consists of associating the future good life with the disappearance of humans as they are now' ([4]: 23). As Comte-Sponville ([10]: 37; [9]: 251) puts it, 'What then can we hope for? Nothing beyond death, so nothing absolute: any contentment of mortals is mortal, and life, if it is worth anything, is only worth something in its finiteness.'

Sense B: Critical In the transhumanist perspective of Stock [36], however, the unhappiness of life consists of continuing to resemble cavemen. 'But this lack of 
change is deceptive', he says. The ultimate state of the human good life can only be obtained via reliance on the notion, as a driving concept, of the development of technological powers that will surpass our biological and cultural limitations to the point of infiniteness (the immortal cyborg). The desire to obtain this becomes the direct condition for, and the engine that drives, the action opposed to humanist and existentialist resignation. This however, does not mean that in the future the good life of the cyborg will no longer be similar to a commitment to being rationally human (as opposed to a commitment to being posthuman): 'In other words, future machines will be human, even if they are not biological' ([22]: 30). What then does the moral measure of the good life of the selfenhancing human being consist of? Stock [36] heeds Marcus Garvey's imperative, which he quotes in the introduction to his book Redesigning Humans: Our Inevitable Genetic Future: 'God and Nature first made us what we are, and then out of our own created genius we make ourselves what we want to be.... Let the sky and God be our limit and Eternity our measurement.' On this understanding, the good life consists of eliminating all suffering (suffering caused by our limitations, aging, diseases, and death) that flows from the human biological condition ([22]: 3; [1]: 27).

\section{The Impasse}

The two senses of the argument based on the good life are irreconcilable. For a humanist, the good life is the best possible life that humans can attain individually and collectively by accepting their human condition of finiteness, because human misfortune resides in the fact that human beings do not know they only need very little to be happy, as well as the fact that they hold onto imaginary needs and limitless desires. For a transhumanist, on the other hand, the good life is the life a person attains as follows: by choosing, as a means of empowerment to escape the present-day image of the imperfect human being, to eliminate through NBICs the suffering inflicted by biological finiteness; and by increasing the desire to move towards the happiness of being perfect and infallible in the image of the immortal cyborg of the future. The impasse once again resides in the justification for the moral argument.
The Impossibility of Providing These Arguments with Foundations That Enable Others to Deem Them Acceptable

The first part of our analysis has shown that once the core meaning of the moral utterances are clearly stated, the dialogical impasses reside in the justification for the moral arguments. Both transhumanists and humanists have bases for justifying the sense they give to each argument. Can we find a philosophical discussion in the literature that demonstrates the superiority of the basis for the claims of one argument over the other? If so, in what way would the critical sense (B) relied on by transhumanists be superior to the affirmative sense (A) argument relied on by the humanists?

The Impossibility of Providing a Foundation for the Argument Based on Nature and Human Nature

With the Christian religion continuing to serve as a fundamental reference point for many people, some transhumanists, like Naam [27], seek to found their interpretation of the arguments based on nature and human nature on the claim that 'playing God', that is, enhancement by technological means, in itself constitutes the fullest expression of human nature:

'Playing God' is actually the highest expression of human nature. The urges to improve ourselves, to master our environment, and to set our children on the best path possible have been the fundamental driving forces of all of human history. Without these urges to 'play God', the world as we know it wouldn't exist today. ([22]: 299)

As an opposing argument, some humanists can point out to transhumanists that, according to the Bible, it is forbidden to 'play God'. An impasse arises here in that still other authors critique this theological approach:

Finally, we will mention here the related, persistent concern that we are playing God with world-changing technologies, which is presumably bad (Peters 2007). But what exactly counts as 'playing God', and why is that morally wrong; i.e., where exactly is the proscription in religious scripture? ([1]: 27; [2]: 252) 
The philosopher Lecourt [26] thus makes the claim that philosophical knowledge of moral issues amounts to nothing but belief. Further, he calls on us to detach ethics from the belief in the Absolute that humanist philosophers have so far tended to cling to as the justification for prohibitions against technological modifications of human nature:

The philosophical question that has not ceased to inform the thought of most philosophers concerned with ethics has been that of founding in the Absolute values on which to base the formulation of maxims capable of entailing everyone's compliance with interdictions and prescriptions.

As Lecourt explains ([26]: 50), this religious tendency could only be sustained until the nineteenth century: since that time, the natural component of the human being has been seen in a biological light.

Humanist detractors, however, denounce the reductive nature of biological conceptions of the human being. For example, since there is nothing to prove that scientific truth can establish a natural, biological order as the basis for a moral argument that will henceforward protect progress from all risks, a humanist like Margaret Somerville [34] invites us to turn instead, for the justification for decisions made in favor of respecting human nature (in the humanist sense), to those moral intuitions that have been widely relied on as truths of the human spirit throughout human history.

Other humanists continue to seek justifications in science for setting biological limits on the technological transformation of humans. For example, the philosophers Leclerc and Trépanier [25] examine the limitations of the biological body of the human being from the strictly scientific perspective (as currently understood), based on studies like biologist Dominique Lambert and philosopher/physicist René Rezsöhazy's Comment les pattes viennent au serpent : Essai sur l'étonnante plasticité du vivant ("How the Snake Got its Feet: An Essay on the Astonishing Plasticity of Living Beings"; [24]).

The debate around the justification for the different senses of the argument based on nature and human nature reveals a clash between religion - or philosophy - based knowledge of the laws of nature and science-based knowledge of the laws of nature. The epistemological question of moral issues is embedded in this debate.
The Impossibility of Providing a Foundation for the Argument Based on Dignity

What might justify submitting to the Kantian argument based on dignity as a basis for ordaining that the human being must not become a technological means to an end other than him or herself (i.e., must not become a cyborg)? To the extent that humanist detractors like Fukuyama rely for their argument on Kant's moral philosophy, which is designed to answer the limitations of metaphysical knowledge and the natural determinism of the phenomenal world studied by science, the moral justification is based on that transcendental inquiry that assumes that we can only have access to that which makes our moral experience possible. If the categorical imperative is experienced as an unconditional imperative, existing in a suprasensible, intelligible world and presenting the ultimate purpose of the human being and the prohibition against treating the human being as a means, then for Kant, this represents the very condition of the moral experience that preserves dignity-autonomy.

But should the current debate between humanism and transhumanism put in doubt this Kantian transcendental analysis, which Fukuyama [15] subscribes to as a way of justifying the position that any technology that does not respect human beings as ends in themselves violates God's will? Is there a transhumanist critique of Kantian dignity that could bring the community of citizens to transform itself into members of a group in a state of dialogue, not to say consensus? If a transhumanist critiques Kant's or Ricoeur's foundation for the argument based on dignity, it is incumbent on her or him to oppose to the transcendental and phenomenological analyses an alternative foundation for analysis. No such critique is explicitly presented in the texts by Kurzweil and Naam included in our study.

On the other hand, it is equally vain to search for texts by transhumanists that demonstrate the validity and superiority of the libertarian concept of dignity involving no constraint on individual freedom to choose. Why should we agree that a strictly libertarian vision of dignity, adduced in support of unconstrained autonomy, is more acceptable than the Kantian concept of dignity as a constraint? No true philosophical debate exists between transhumanism and humanism on the rational foundations for the use of the idea of dignity in either sense. 
The Impossibility of Providing a Foundation

for the Argument Based on the Good Life

Does there exist a debate that demonstrates that Ricoeur's vision of the humanist sense of the good life is superior to the transhumanist sense? Why should we accept the humanists' view that the good life is the best possible life that humans can attain for themselves, both individually and collectively, by accepting the human condition of finiteness? In Fallible Man, Ricoeur [32] presents an analysis based on the philosophical method of phenomenology. Ricoeur turns to the discourse of the pathos of wretchedness from Plato to Pascal to justify the position that human beings, who are determined by their natural finiteness and the anguish that flows from being destined to die (up to Kierkegaard), can only embark on the good life on one condition: acceptance of their finiteness in all its Kantian categories (time, space, causality, destiny), which incites them to assign a meaning to human life in the face of the experience of suffering and death. He quotes Kant: "For to be in need of happiness and also worthy of it and yet not to partake of it could not be in accordance with the complete volition of an omnipotent rational being if we assume such...." (qtd. in Ricoeur [32]: 67). The humanist Dupuy [12, 13, 14] seems to be taking the same phenomenological approach as Ricoeur when he states that one of the main philosophical errors made in dealing with human enhancement consists of confusing human nature with the human condition (that is, the human biological condition) and of thus failing to face the question of the impact of technologies on the human condition:

There is another major philosophical error which mars the contributions to bioethics or nanoethics that I have read: they almost always confuse human nature and the human condition. They raise questions about the impact of technologies on human nature to which, as they probably know full well, no answer can be given, and this allows them to avoid raising the same questions with respect to the human condition.

From this phenomenological position, he argues [12]:

The problem no longer consists of knowing up to what point we may or may not transgress nature. The problem, rather, is that the very notion of transgression is at the point of losing all meaning. Human beings will no longer encounter anything other than a world that mirrors humanity's own artificial creations. ([12]: 66)

But on what basis could a transhumanist convince a humanist that the phenomenological approach to the justification for conceptions of the good life should be abandoned in favour of another approach that justifies the transhumanist conception? The transhumanist critique consists of no more than saying that it is difficult to judge in advance what the perspective of the enhanced human will be, given that in the present we continue to be limited by our condition of finiteness.

An observation by Margaret Somerville clearly illustrates the problem of the justification for moral arguments. Since it is impossible to provide objective proofs of metaphysical beliefs (it's not a question of demonstrable fact), and since certain kinds of knowledge (for example, moral intuitions that have been widely shared for a long time) do not constitute 'exact sciences', relativists reject these beliefs and these kinds of knowledge. Instead they rely exclusively on fact demonstrated by 'pure' or technical reasoning:

The common ground between those who take a principle-based approach to ethics (many of whom found their principles in religious or spiritual beliefs) and many, but not all, of those who are moral relativistists is that both believe they know and are promoting the truth-or at least a partial truth. Their polarization results from the opposite content of what they believe that truth to be.

The resulting conflict can never be resolvedbut again, it has to be accommodated ([34]: 195).

\section{The Difficulty of Applying the Argument to a Specific Situation}

In the debate between humanism and transhumanism, the dialogical impasse arises not only, as we have seen so far, in relation to the 'moral utterance' and the 'justification' components of a moral argument; but also in relation to the 'application to a specific case' component. What is common to the practical reasoning of all the humanist arguments is that the application of a moral argument to a specific case 
always consists of a reasoning process that starts from the general moral utterance and moves to a specific situation. In order to ensure the passage from the general to the particular, intermediate categories are needed. Each moral argument requires specific intermediate categories.

- In order to apply the argument based on nature and human nature, humanists refer us to the a priori distinction between the natural (the biological) and the artificial (the technological) that serves as a guide for defining the limits for projects for human enhancement. For example, if a scientist proposes a project to implant an electronic chip in order to increase the capabilities of the human brain, humanist reasoning would consist of saying that the chip derives from artifice and does not respect that which is of the natural.

- In order for the Kantian argument based on dignity as a constraint (i.e., dignity in the humanist sense A) to be able to prohibit all cases of transformation of the human being into a cyborg, Fukuyama forcefully insists, as Naam [27] observes, on applying the a priori distinction between that which relates to therapy and that which relaters to human enhancement:

Fukuyama would like to restrict more than just technologies for engineering genes, arguing that governments need to 'draw red lines' around technologies in general, 'to distinguish between therapy and enhancement, directing research toward the former while putting restrictions on the latter'.

- In order for the moral argument based on the good life to serve to prohibit various possible development plans for brain-machine interfaces or cyborgs (as proposed in the discourse of human enhancement), the humanists begin with the a priori distinction between human limitations (the biological condition of finiteness) that are to be accepted and the desideratum of no human limitations (infiniteness).

On the other hand, however, the transhumanists do not need such a priori distinctions in order to apply their moral arguments, because their moral posture does not impose any limitations on action. Nevertheless, they share the same conception of practical reasoning, because they critique the validity of these humanist distinctions by requiring that they be a priori clear and precise.

The transhumanists' application of their moral arguments to a specific case follows the same line of reasoning from a general principle to a specific case. But since their general principles do not impose a limit on certain actions, all human transformations are permissible. The transhumanists also seem to share the same framework for practical reasoning as the humanists, as is shown by the controversies over the a priori distinctions brought forward by the humanists' arguments.

- Critical philosophers like Allhoff et al. [1] make the point that they cannot continue defending the use of the analytical distinction between the natural and the artificial: 'However, the natural-versusartificial distinction, as a way to identify human enhancements [or unnatural enhancements], may prove most difficult to defend given the vagueness of the term "natural".' In this context of the ethics of human enhancement, the nature of the natural (the biological) is vague precisely because the natural is joined to the artificial (the technological), which is in question. For example, the dream of implanting an NBIC chip (viewed as artificial) designed to a nanometric scale $\left(10^{-9} \mathrm{~m}\right)$ presupposes that this chip will meld into those biological conditions ([8]: 34).

- Transhumanists respond to humanists like Fukuyama that the application of the a priori distinction between therapy and enhancement, as a way of protecting the human being as an end in its bodily and spiritual integrity, is not clear. On the contrary, it is vague, because therapy (for example, therapeutic applications of nanotechnological machines such as neurological prostheses used to repair nervous-system damage causing diminished capacities) blends into human enhancement (for example, increasing the capacity of the human brain by means of the use of even more advanced nanotechnological machines that increase the speed of interface, raising it to a higher level than normal). In one of his arguments, Naam reasons that if we ban all research that focuses on enhancement, we automatically ban most research on healing the sick and injured ([27]: 5). 
- For Allhoff et al. [1], "the notion of "the good life" becomes vacuous in the sense of being even a vague guide for action,' precisely because this a priori distinction between certain human limitations (the human biological condition) that must be accepted and those human limitations that it is permissible to alter without limitations is not sufficiently clear to be considered a point of departure:

In the future, with human enhancements, things will be less clear. Do we know if particular 'enhancements' will improve life? Will enhanced people be happier, and if not, why bother with enhancements? Can we say much about the 'good life' for an 'enhanced' person?

The debate between humanists and transhumanists regarding the 'application to a specific case' component of moral arguments shows us that: (1) both sides share the same framework, that of reasoning from the general principle to a specific case; and (2) there exists a need for a priori distinctions of intermediate categories. In the transhumanists' view, their own critique of the humanists' inability to make clear-cut distinctions reveals the rational superiority of the transhuhumanist position. But is this the case?

According to Allhoff et al. [1], the fact that distinctions are somewhat vague a priori doesn't necessarily mean that they are to be written off. The solution proposed consists of maintaining that these distinctions can only be made on a case-by-case basis; that is, they become clear a posteriori. This is well illustrated by the 'paradox of the heap':

Given a heap of sand with $\mathrm{N}$ number of grains of sand, if we remove one grain of sand, we are still left with a heap of sand (that now only has N - 1 grains of sand). If we remove one more grain, we are again left with a heap of sand (that now has $\mathrm{N}$ 2 grains). If we extend this line of reasoning and continue to remove grains of sand, we see that there is no clear point $P$ where we can definitely say that a heap of sand exists on one side of $P$, but less than a heap exists on the other side. In other words, there is no clear distinction between a heap of sand and a less-than-a-heap or even no sand at all.

However, the wrong conclusion to draw here is that there is no difference between them or that the distinction between a heap and no-heap should be discarded (or between being bald and having hair, as a variation of the paradox goes). Likewise, it would seem fallacious to conclude that there is no difference between therapy and enhancement or that we should dispense with the distinction. It may still be the case that there is no moral difference between the two, but we cannot arrive at it through the argument that there is no clear defining line or that there are some cases (such as vaccinations, etc.) that make the line fuzzy. As with 'heap', the terms 'therapy' and 'enhancement' may simply be vaguely constructed and require more precision to clarify the distinction.

Kurzweil [22] questions this paradox, wondering where the distinction between the human and the posthuman lies:

If we regard a human modified with technology as no longer human, where would we draw the line? Is a human with a bionic heart still human? How about someone with a neurological implant? What about two neurological implants? How about someone with ten nanobots in his brain? How about 500 million nanobots? Should we establish a boundary at 650 million nanobots: under that, you're still human and over that, you're posthuman?

Allhoff's comments indicate that there are other ways of conceptualizing the 'application to a specific case' component of a moral argument.

\section{The Ineffectiveness of Moral Argument in a Democratic Society}

The final impasse between moral arguments that arises in the humanist-transhumanist debate opposes the arguments based on nature and human nature, dignity, and the good life to the arguments based on autonomy and rights. As we have seen, the core meaning of the transhumanist argument based on dignity is actually the same as that of the moral argument based on autonomy and rights. The two arguments are usually combined, because in order to live in society, the autonomy of one must be the limit of the autonomy of the other [7]; and this is why the democratic recognition of rights exists.

The debate here is focused on the possibility of using moral argumentation in a democratic society in order to justify regulating nanotechnology.

The first critique concerns the appeal to religious foundations for moral arguments. 
For example, can a religious argument around nature and human nature be imposed on the law of a secular society?

In reality, it is hard to condemn transgressions of the natural order, given that such transgressions are a constant in the history of human activity. And as a matter of principle, transgression of the divine order could, for its part, not be condemned as such in a secular society. ([28]: 119)

Furthermore, in this same context of law within a secular society, what is the value of the argument based on dignity in its humanist, Kantian sense.

The most flagrant problem here is the fact that it is a struggle to give a clear meaning to this notion of 'human dignity', which serves as a kind of hold-all and makes it possible to condemn without having to engage in further argument - and that is precisely the difficulty when what we are seeking here is the basis for a process of moral argumentation on nanotechnologies. For this reason, obligation-based ethics are no more effective in convincing us that nanoethics are necessary. ([28]: 119-120)

But what moral validity would attach to the democratic solution to this question of the social acceptability of the morally good life of human beings enhanced by NBICs, without rational debate on that same validity in such a society? We can only assume that the democratic solution applied to NBICs, absent true philosophical debate, is inefficient because it merely entrenches moral subjectivism. The democratic argument presupposes a moral theory known as moral subjectivism; but why should we take moral subjectivism to be superior to other moral arguments? Rather than being a moral argument, democracy is in fact more of a modus operandi that serves to avoid the logical impasses we arrive at. Dupuy [11] denounces the absence of moral inquiry from this modus operandi as found in France:

Does moral philosophy allow us to see clearly in this field? Certainly, the answer to this question is not to be found in France. There, philosophers and members of the military don't talk to each other, and it's in the political arena that the task of deciding one of the most fundamental issues in the life of a nation is performed. Democracy is yet again serving as a pretext for the absence of moral inquiry. But the ritual of the vote will never replace rational debate. We must look to America.

Finally, decision making on regulation of nanotechnology in democratic societies always involves a trade-off between economic wealth and quality of life. How does democracy apply its general principle to a specific case?

The danger is to think of the future simply in terms of economic development. Sarewitz argues that there is a difference between developing technologies that improve quality of life and developing technologies that stimulate economic growth with the (sometimes mistaken) presumption that economic growth will lead to improvements in the quality of life. ([20]: 29)

\section{Conclusion}

The philosophical debate between humanism and transhumanism around the question of the social acceptability of NBICs for the purposes of human enhancement has so far been mired in impasse because of the various argument-based difficulties that we have just analyzed, which can be summarized as follows.

1. The ambiguity of the types of moral argument used: nature and human nature; dignityautonomy; the good life. The ambiguity results from the fact that a single name for a concept does not suffice to convey the precise meaning of the moral utterance being deployed. That is why it can serve for both positive and negative evaluations of the development of NBICs. This difficulty does not constitute an impasse if humanists and transhumanists will agree to define the sense assigned to the key concepts (nature, dignity, the good life). A clear utterance of the moral argument, combined with specific statements about the justifications for these utterances, will help overcome the impasse related to meaning and will contribute to more clearly identifying the impasse related to justification.

2. Every moral argument has its own justification. In the texts we have analyzed, there is very little 
discussion of the justification for these arguments. Moreover, we found no debate whatever about the superiority of a given justification for an argument. No one can provide reasons that make it possible to say the moral obligation they are advancing on the basis of nature, dignity, or the good life is based on reason. The absence of debate about the rationality of the grounds for justifying a moral argument seems to confirm that morality is no more than a matter of beliefs and lies outside any form of rationality. The absence of consensus on how to reconcile these irreconcilable arguments is clear.

3. What does the debate over the application of a moral utterance to a specific case reveal? Both transhumanists and humanists share the same conception of practical reason, requiring that certain distinctions be made clear and precise a priori in order to apply a given argument to a situation. Perhaps this position should be reexamined in light of the discussion of a priori and a posteriori. Is it necessary, for purposes of practical reasoning, to have a priori distinctions or a posteriori ones? Must we reject all distinctions that are a priori? The fact that distinctions made a priori are vague does not necessarily mean they should be written off. As 'the paradox of the heap' so effectively illustrates, the proposed approach to a solution consists of saying that it is only case-by-case that the senses of the distinctions will become clear a posteriori.

4. The final impasse is quite complex because it is twofold. In this article we are strictly analysing the impasse related to moral arguments. The question of how we can articulate a place for moral debate in a democratic society is another matter. In the encounter between the arguments of humanists and those of transhumanists, moral limitations on autonomy are opposed to democratic social limitations on autonomy (rights). This debate on moral and legal limitations to nanotechnology seems to revisit the basic assumption that positive law embodies the separation of law and morals.

Behind the impression of routine recourse to moral arguments in nanoethics lie a number of dialogical impasses that we have identified under four headings. When philosophers take part in an interdisciplinary dialogical process of ethical, economic, environmental, legal, and social evaluation of nanotechnology, they are confronted with these impasses and must try to find answers.

Acknowledgments This study is currently being funded by a grant from the Canadian Institutes of Health Research (CIHR:43854) entitled: Development of an interdisiciplinary framework for the analysis of the impact of nanotechnologies on health and of their social acceptability.

Open Access This article is distributed under the terms of the Creative Commons Attribution Noncommercial License which permits any noncommercial use, distribution, and reproduction in any medium, provided the original author(s) and source are credited.

\section{References}

1. Allhoff F, Lin P, Moore J, Weckert J (2009) Ethics of human enhancement: 25 Questions \& answers. (US National Science Foundation Report)

2. Allhoff F, Lin P, Moore D (2010) What is nanotechnology and why does it matter?: From science to ethics. WileyBlackwell, Chichester

3. Bégorre-Bret C (2004) Bioéthique et posthumanité. In: F Fukuyama, La fin de l'homme: Les conséquences de la révolution biotechnique J. Habermas, L'avenir de la nature humaine. Vers un eugénisme libéral D. Lecourt, Humain, post-humain [Electronic version]. Les études philosophiques, 253-269

4. Besnier J-M (2009) Demain les posthumains: Le futur a-t-il encore besoin de nous? Hachette Littératures, La Flèche

5. Bostrom N (2005) In defense of posthuman dignity [Electronic version]. Bioethics 19:202-214

6. Brownsword R (2008) Regulating nanomedicine - The smallest of our concerns? NanoEthics 2:73-86. doi: $10.1007 / \mathrm{s} 1156900800302$

7. Burkhardt J (2008) The ethics of agri-food biotechnology: How can an agricultural technology be so important? In: David K, Thompson PB (eds) What can nanotechnology learn from biotechnology? Elsevier, London, pp 55-79

8. Comité d'éthique du Centre national de la recherche scientifique (COMETS) (2006) Avis Enjeux éthiques des nanosciences et des nanotechnologies. Retrieved March 15, 2011, from http://www.cnrs.fr/fr/presentation/ ethique/comets/index.htm

9. Comte-Sponville A (2001) Dictionnaire philosophique Perspectives critiques. Presses Universitaires de France, Paris

10. Comte-Sponville A, Ferry L (1998) La sagesse des modernes. Dix questions pour notre temps. Éditions Robert Laffont, Paris

11. Dupuy J-P (2002) Pour un catastrophisme éclairé. Quand l'impossible est certain. Éditions du Seuil, Paris

12. Dupuy, J-P (2004) Le problème théologico-scientifique et la responsabilité de la science: Les effets sur le rapport à la nature (effets ontologiques). Retrieved August 12, 2010, from http://formes-symboliques.org/article.php3? id_article $=66$ 
13. Dupuy J-P, Roure F (2004) Les nanotechnologies: éthique et prospective industrielle, Tome 1 (France, Conseil Général des Mines, Conseil Général des Technologies de l'Information) Retrieved May 15, 2009, from http://www. cgm.org/themes/deveco/develop/nanofinal.pdf

14. Dupuy J-P (2007) Some pitfalls in the philosophical foundation of nanoethics. J Med Philos 32:237-261. doi:10.1080/03605310701396992

15. Fukuyama F (2002) Our posthuman future: consequences of the biotechnology revolution. Farrar, Straus \& Giroux, New York

16. Fukuyama F (2006) Beyond bioethics: a proposal for modernizing the regulation of human biotechnologies. School of Advanced International Studies, John Hopkins University, Washington

17. Grunwald A, Julliard Y (2007) Nanotechnology - Steps towards understanding human beings as technology? NanoEthics 1:77-87. doi:10.1007/s115690070010

18. Habermas J (2002) L'avenir de la nature humaine: vers un eugénisme libéral? Gallimard, Paris

19. Jean MS (2006) L'homme biotech: une problématique éthique internationale. In: Béland J-P (ed) L'homme biotech: humain ou posthumain. Presses de l'Université Laval, Québec, pp 5-12

20. Johnson DG (2007) Ethics and technology 'in the making': an essay on the challenge of nanoethics. NanoEthics 1:2130. doi: $10.1007 / \mathrm{s} 1156900700067$

21. Kant, Immanuel [1785] (1993) Grounding for the metaphysics of morals, translated by James W. Ellington, 3rd ed. (Indianapolis: Hackett)

22. Kurzweil R (2005) The singularity is near: when humans transcend biology. Viking Penguin, New York

23. Lalande A (2002) Vocabulaire technique et critique de la philosophie. Presses Universitaires de France, Paris

24. Lambert D, Rezsöhazy R (2004) Comment les pattes viennent au serpent? Essai sur l'étonnante plasticité du vivant. Flammarion, Paris

25. Leclerc B, Trépanier G (2006) L'être humain est-il perfectible et expérimentable? Réflexions autour du postulat transhumaniste de la plasticité du vivant. In: Béland J-P (ed) L'homme biotech: humain ou posthumain. Presses de 1'Université Laval, Quebec, pp 45-65

26. Lecourt D (2003) Humain post humain. Presses Universitaires de France, Paris

27. Naam R (2005) More than human: embracing the promise of biological enhancement. Broadway Books, New York

28. Nurock V (2008) Avons-nous vraiment besoin de 'nano-éthique'? In: Bensaude-Vincent B, Larrère R, Nurock V (eds) Bionano-éthique, perspectives critiques sur les bionanotechnologies. Éditions Vuibert, Paris, pp $55-71$

29. Paris C, Bastarache Y (1995) Philosopher: pensée critique et argumentation. Éditions C.G, Quebec

30. Patenaude J, Legault GA, Béland J-P, Boissy P, Parent M (2011) Moral arguments in the debate over nanotechnologies: Are we talking past each other? NanoEthics. doi:10.1007/s11569-011-0132-0

31. Ricoeur P ([1990]1992) Oneself as another, translated by Kathleen Blamey (Soi-même comme un autre). University of Chicago Press, Chicago

32. Ricoeur P ([1960]1986) Fallible Man, translated by Charles A. Kelby (Finitude et culpabilité 1. L'homme faillible), rev. ed. Fordham University Press, New York

33. Roco M, Bainbridge WS (2003) Converging technologies for improving human performance: Nanotechnology, biotechnology, information technology and cognitive science. Kluwer Academic Publishers, Dordrecht

34. Somerville M (2006) The ethical imagination: journeys of the human spirit. Anansi, Toronto

35. Stock G (1993) Metaman: the merging of humans and machines into a global superorganism. Simon \& Schuster, New York

36. Stock G (2002) Redesigning humans: our inevitable genetic future. Houghton Mifflin Company, Boston

37. Theis R (2005) L'impératif catégorique, des énoncés à l'énonciation. Le portique. Retrieved November 22, 2010, from http://leportique.revues.org/index597.html 